\title{
H3C14 Gene
}

National Cancer Institute

\section{Source}

National Cancer Institute. H3C14 Gene. NCI Thesaurus. Code C154645.

This gene plays a role in the incorporation of DNA into nucleosomes. 